\title{
PERBANDINGAN METODE SVM, FUZZY-KNN, DAN BDT-SVM UNTUK KLASIFIKASI DETAK JANTUNG HASIL ELEKTROKARDIOGRAFI Uswatun Hasanah ${ }^{1}$, Lintang Resita M. $_{4}^{2}$, Andhica Pratama ${ }^{3}$, Imam Cholissodin
}

\author{
${ }^{1}$ Teknik Informatika, Fakultas Ilmu Komputer, Universitas Brawijaya \\ ${ }^{2}$ Teknik Informatika, Fakultas Ilmu Komputer, Universitas Brawijaya \\ ${ }^{3}$ Teknik Informatika, Fakultas Ilmu Komputer, Universitas Brawijaya \\ Email: ${ }^{1}$ uswah94line@gmail.com
}

(Naskah masuk: 8 Agustus 2016, diterima untuk diterbitkan: 8 September 2016)

\begin{abstract}
Abstrak
Perkembangan Ilmu Pengetahuan dan Teknologi (IPTEK) semakin pesat terutama dalam bidang kesehatan. Elektrokardiografi (EKG) merupakan salah satu metode untuk menentukan kondisi jantung manusia yang direpresentasikan dalam bentuk gelombang. Jantung merupakan organ vital manusia dan merupakan pertahanan hidup terakhir manusia selain otak. Di Indonesia berdasarkan data dari Kementrian RI tahun 2013, kematian akibat penyakit jantung ini diperkirakan sebesar 0.5\% atau 883.447 orang dan berdasarkan gejala sebanyak $1.5 \%$ atau sekitar 2.650 .340 orang. Kelas dari klasifikasi ini terdiri dari normal dan aritmia. Dimana aritmia terdiri dari atrial fibrillation, PVC bigeminy, dan ventricular tachycardia. Data didapatkan dari MITBIH Arrhytmia Database. Penelitian ini bertujuan untuk menentukan klasifikasi dari sinyal gelombang EKG tersebut dengan membandingkan metode Support Vector Machine dengan strategi One Against All, Fuzzy KNearest Neighbor, dan menggunakan metode Binary Decision Tree - Support Vector Machine. Hasil klasifikasi yang didapatkan dengan metode SVM memiliki rata-rata akurasi sebesar $81.30 \%$ menggunakan dataset dari fitur 3601 MLII dengan kernel Polynomial, metode Fuzzy-KNN 81.25\% menggunakan jarak Manhattan, dan BDT-SVM sebesar 70.00\% menggunakan kernel Polynomial dengan menggunakan data sebesar 140 dataset.
\end{abstract}

Kata Kunci: Support Vector Machine, Binary Decision Tree, Fuzzy-KNN, Detak Jantung, Elektrokardiografi

\begin{abstract}
The development of Science and Technology growing rapidly, especially in the health field. Electrocardiography (ECG) is one method for determining the condition of the human heart rate that is represented in the form of waves. The human heart is a vital organ and is the last surviving human defense other than the brain. In Indonesia based on data from the Ministry of Indonesia in 2013 , the death from heart disease is estimated about $0.5 \%$ or 883.447 people and is based on the symptoms as much as $1.5 \%$, or about 2.65034 million people. Class of this study such as normal and arrhythmias. Arrhythmias consists of atrial fibrillation, PVC bigeminy, and ventricular tachycardia. Data collected from the MIT-BIH Arrhythmias Database. This study aims to determine the classification of the ECG waveform signal by comparing SVM algorithm is supported by One Against All of the strategies, Fuzzy K-Nearest Neighbor, and Binary Decision Tree - Support Vector Machine. The average results of classification using SVM have an accuracy of $81.30 \%$ by using a dataset from 3601 MLII features with the polynomial kernel, $81.25 \%$ with Fuzzy-KNN by Manhattan Distance, and $70.00 \%$ with BDT-SVM using polynomial kernel using data of 140 datasets.
\end{abstract}

Keywords: Support Vector Machine, Binary Decision Tree, Fuzzy-KNN, Heart Rate, Electrocardiography.

\section{PENDAHULUAN}

Elektrokardiografi (EKG) adalah tes yang digunakan untuk mengukur aktivitas listrik detak jantung [American Heart Association, 2015]. Jantung adalah organ vital dan merupakan pertahanan terakhir untuk hidup selain otak dan sebagai salah satu bagian dari tubuh manusia yang memiliki peran sebagai pusat beredarnya darah [Shympto Diagnosiso, 2016]. Pada tahun 2008, diperkirakan lebih dari 3 juta kematian akibat penyakit jantung. Kematian dini sebesar $4 \%$ di negara berpenghasilan tinggi dan $42 \%$ di negara berpenghasilan rendah. Berdasarkan diagnosis dokter, jumlah penderita penyakit jantung koroner di Indonesia pada tahun 2013 yaitu sebesar $0,5 \%$ atau diperkirakan sekitar 883.447 orang, sedangkan berdasarkan diagnosis dokter/gejala sebesar 1,5\% atau diperkirakan sekitar 2.650 .340 orang. Berdasarkan diagnosis/gejala, estimasi jumlah penderita penyakit jantung koroner terbanyak terdapat di daerah Provinsi Jawa Timur sebanyak 375.127 orang $(1,3 \%)$ [Nico, 2015]. Menurut data dari WHO bahwa penyumbang kematian akibat 
penyakit jantung, sekitar 30,5\% kematian warga dunia dan $30 \%$ sebagai penyumbang kematian di Indonesia [Kesehatan, Kementrian RI, 2013]. Pemeriksaan denyut jantung adalah langkah awal yang digunakan setiap tenaga medis. Denyut jantung atau denyut nadi adalah tanda penting dalam bidang medis yang bermanfaat untuk mengevaluasi dengan cepat kesehatan atau mengetahui kebugaran seseorang secara umum. Sehingga dengan mengetahui irama denyut jantung akan membantu tenaga medis dalam pemeriksaan.

Aritmia yang dikenal sebagai suatu kondisi di mana laju detak jantung berdetak terlalu cepat, terlalu lambat atau tidak teratur. Aritmia jantung umumnya tidak berbahaya. Namun, beberapa jenis aritmia jantung dapat menyebabkan gangguan kesehatan atau bahkan sampai mengancam nyawa [Adnamazida, Rizqi, 2013]. Data statistik menunjukkan bahwa 5 dari 1.000 orang mengalami aritmia. Jika ini terjadi, maka periksakanlah ke dokter dan jalani tes EKG. Saat ini pemeriksaan EKG sudah merupakan bagian pemeriksaan rutin untuk setiap pemeriksaan kesehatan dasar untuk karyawan baru, melanjutkan sekolah, atau masuk asuransi [Amazine.co, 2016]. Tidak hanya dokter, saat ini perawat pun dituntut untuk bisa membaca hasil perekaman EKG. Fakta yang ada di lapangan, bahwa persentase perawat yang bisa melakukan hal tersebut masih kecil, padahal sebagian besar layanan kesehatan, baik rumah sakit maupun klinik, sudah dilengkapi dengan fasilitas EKG [JJ, 2013]. Membaca EKG harus dengan sifat tenang dan konsentrasi, bahkan ahli kardiologi jika tidak tenang dalam membaca hasil EKG maka akan memberikan analisa yang salah. Banyak yang perlu dipersiapkan terlebih dahulu sebelum menganalisa hasil EKG yaitu harus menentukan iramanya dengan menghitung RR Interval serta harus menghitung nilai normal tiap gelombang, kemudian menentukan berapa aksis jantungnya dan pembesaran jantung sehingga mendapatkan hasil analisa terakhir. Selain itu kadang-kadang ditemukan adanya gambaran EKG yang tidak khas dan dapat membingungkan [Merdeka, Suara, 2015].

Dalam penelitian ini menggunakan metode yaitu SVM, Fuzzy-KNN, dan BDT-SVM. Prinsip dasar dari metode SVM adalah mencari hyperplane pemisah antara kelas positif dan kelas negatif [FK Universitas Hasanudin, 2009]. Salah satu kelebihan dari metode SVM adalah mampu menangani kasus dengan input space yang berdimensi tinggi. Namun, SVM juga memiliki kelemahan, salah satunya adalah komputasi yang lama untuk proses klasifikasi [Imaduddin, Zaki, Abidzar T., Hilmy, 2015.]. Seiring berkembangnya teknologi, muncul beberapa perkembangan metode SVM yang mampu menyelesaikan kasus multi kelas, salah satunya adalah dengan strategi One Against All dan metode Binary Decision Tree SVM (BDT-SVM). Dimana metode BDT-SVM ini memiliki kelebihan yaitu mendapatkan penentuan kelas yang lebih dinamis yang didasarkan pada jarak euclidean. Selain itu juga menggunakan metode Fuzzy-KNN untuk penentuan klasifikasi ini.

Pada penelitian sebelumnya yaitu berjudul "Prediction Based on Support Vector Machine for Travel Choice of High-Speed Railway Passenger in China" membahas tentang prediksi kereta api yang dipilih penumpang dimana hal ini dapat meningkatkan daya saing pada pasar transportasi sehingga pelayanan kereta api kecepatan tinggi menjadi lebih baik. Prediksi ini menggunakan metode SVM dimana hasil akurasi yang didapatkan adalah 91.44\% [Madzarov, Gjorgji, Gjorgjevikj, Dejan, \& Chorbev, Ivan, 2008]. Kemudian penelitian lainnya yaitu "Detect Pedestrian Orientation by Integrating Multiclass SVM Utilizing Binary Decision Tree" [Shu, K., Jing, L., Mei, L., Xin, Z., 2011]. Penelitian ini untuk memprediksi kemungkinan terjadi tabrakan dengan mendeteksi arah pejalan kaki menggunakan metode yang sama yaitu binary decision tree-SVM menggunakan dataset INRIA yang terdiri dari 2000 gambar. Hasil akurasi untuk Non-Ped (Bukan pejalan kaki) sebesar $100 \%$, depan dan kiri sebesar $99 \%$, kanan sebesar $95 \%$, dan belakang sekitar $90 \%$. Selain penelitian diatas, juga melakukan kajian terhadap penelitian dengan judul Penelitian kedua mengenai penerapan metode Fuzzy K-NN untuk menentukan kualitas hasil rendemen tanaman tebu oleh Rahmi, dkk, menunjukkan bahwa FK-NN merupakan metode yang baik untuk memecahkan masalah klasifikasi, dimana pada penelitian ini akurasi tertinggi mencai 98\% dengan penggunaan 175 data latih dan 80 data uji [Santoshi, G., Pushpa, G. Gowri, 2015].

Dari beberapa permasalahan diatas, perlunya dibuat suatu sistem yang mampu mengklasifikasikan kondisi detak jantung berdasarkan hasil pemeriksaan elektrokardiografi (EKG) menggunakan binary decision tree-support vector machine untuk membantu pemeriksaan pada jantung sehingga diharapkan bisa menjadi salah satu bentuk penanggulangan dengan langkah kecil dalam masalah Jantung di Indonesia serta dapat membantu para medis dari perawat hingga dokter dalam mengklasifikasikan hasil pemeriksaan EKG.

\section{LANDASAN KEPUSTAKAAN}

Jantung (dalam bahasa Latin yaitu cor) adalah rongga organ berotot yang memiliki tugas untuk memompa darah melalui pembuluh darah oleh kontraksi berirama yang terjadi secara berulang [Shofia, Rahmi Amiratus, dkk. 2013]. Denyut jantung yang normal merupakan tanda kesehatan pada tubuh yang baik secara keseluruhan. Detak jantung yang normal akan terasa lebih cepat berdetak atau lebih lambat tergantung dari aktifitas yang sedang dikerjakan. Berdasarkan namanya, 
aritmia (a yaitu tidak, ritmia yaitu ritmik atau irama). Sehingga aritmia (gangguan irama jantung) adalah kondisi di mana irama jantung tidak normal. Pada kasus ini penderita bisa memiliki irama jantung yang terlalu cepat atau lambat yang tidak sesuai dengan aktifitas yang sedang dikerjakan [Sindo, 2010]. Dibawah ini merupakan klasifikasi dari aritmia.

\section{a. Atrial Fibrilation}

Fibrilasi bilik jantung atrium (Atrial fibrillation (AF) merupakan suatu kondisi ritme jantung tidak normal yang paling umum dan menyerang jutaan manusia di seluruh dunia. Kondisinya meliputi aktifitas yang sangat cepat dan tidak beraturan dalam atria dan menimbulkan gejala-gejala seperti jantung berdebar, sakit kepala, kehilangan kesadaran, sesak nafas dan rasa letih. Fibrilasi bilik jantung atrium (AF) juga merupakan penyebab umum dari stroke yang rata-rata menyerang $5 \%$ mereka dengan fibrilasi bilik jantung atrium (AF) setiap tahunnya [Pendidikan, Dosen, 2014].

\section{b. PVC Bigeminy}

PVC Bigeminy adalah terjadinya PVC pada setiap detaknya. PVC (Premature Ventricular Contractions) atau ventrikel kontraksi prematur adalah denyut jantung yg terjadi sebelum waktunya yang berasal dari ventrikel jantung. Pada ventricular bigeminy keadaan PVC lebih sering dialami dan dinyatakan sedikit berbeda dari jenis PVC lainnya. Sehigga jika perubahan terbaru dalam irama detak jantung terjadi, harus dilakukan pemeriksaan jantung dan fungsi hati serta tes darah [The Harley Street Clinic, 2012].

c. Ventricular Tachycardia

Takikardia adalah denyut jantung yang terjadi lebih cepat daripada denyut jantung normal. Takikardia disebabkan oleh suatu kelainan di dalam jantung sehingga menghasilkan sinyal listrik yang cepat. Dalam beberapa kasus, takikardia tidak menimbulkan komplikasi. Namun, takikardia yang parah dapat mengganggu fungsi normal jantung, meningkatkan risiko stroke, atau menyebabkan serangan jantung mendadak atau kematian [Cardiac Health, 2016].

Rekaman listrik jantung yang dihasilkan EKG dapat memberi petunjuk adanya beberapa kelainan jantung seperti Gangguan irama jantung, Penyakit jantung koroner, Serangan jantung, Penebalan otot jantung dan pembesaran rongga jantung [Dr. Tryzelaar, 2016.]. Dibawah ini pada Gambar 1 merupakan alat EKG.

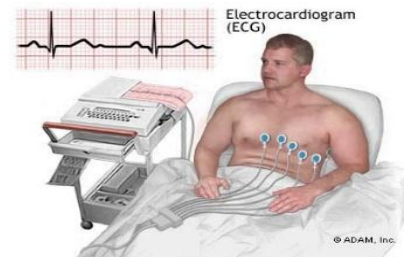

Gambar 1. Alat EKG.
Dalam pemeriksaan elektrokardiografi (EKG), untuk mendapatkan hasil pemeriksaan yang lebih akurat dibutuhkan 12 sadapan hasil rekam EKG. 12 sadapan itu antara lain $I, I I, I I I, a V R, a V L, a V F, V I$, $V 2, V 3, V 4, V 5, V 6$.
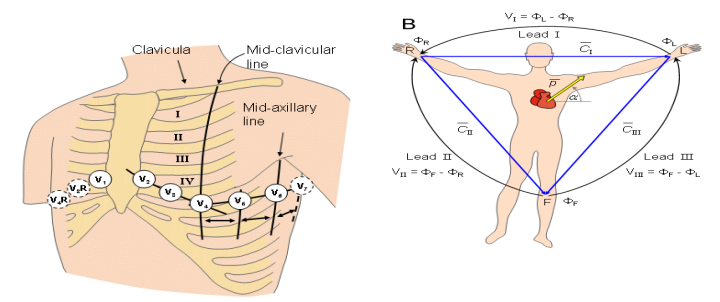

Gambar 2. 12 Sadapan EKG.

Pada penelitian ini digunakan sadapan dari kanal MLII dan V1. MLII atau modified lead II merupakan penempatan elektroda di lengan kanan dan tungkai kiri, dengan tungkai kiri positif. VI digunakan untuk memeriksa sinyal rendah, dan untuk sinyal atas elektroda juga ditempatkan di dada. Vl merupakan sadapan pada sela iga keempat sebelah kanan dari sternum seperti yang terlihat pada Gambar 2 di atas [Moody, G.B., 2010].

Klasifikasi adalah salah satu aspek dalam data mining. Klasifikasi merupakan proses untuk menemukan model yang menggambarkan kelas data atau konsep dengan tujuan agar dapat memprediksi kelas dari objek yang label kelas tidak diketahui. Dimana dapat menemukan model yang menggambarkan dan membedakan kelas data atau konsep [Point, Tutorials (I), pvt.LTD, 2014].

Support Vector Machine (SVM) adalah sebuah metode klasifikasi biner yang dikembangkan oleh Vapnik dan rekan-rekannya di Laboratorium Bell, yang merupakan algoritma lanjutan pada perbaikan yang dilakukan pihak lain [Imaduddin, Zaki, Abidzar T., Hilmy, 2015]. Algoritma ini bertugas untuk memisahkan hyperplane terbaik yang terdiri dari 2 kelas yaitu positif dan negatif [FK Universitas Hasanudin, 2009].

1. SVM Non-Linear

Pada umumnya masalah dalam domain dunia nyata (real world problem) jarang yang bersifat linear separable. Kebanyakan bersifat non linear. Untuk menyelesaikan problem non linear, SVM dimodifikasi dengan memasukkan fungsi Kernel [Point, Tutorials (I), pvt.LTD, 2014].

\section{Sequensial Training SVM}

Metode sequential training SVM yang digunakan sebagai alternatif sederhana untuk menemukan hyperplane optimal. Algoritmanya yaitu sebagai berikut [Satriyo Nugroho, Anto, Budi Witarti, Arief, \& Handoko, Dwi, 2003].

a. Inisialisasi $\alpha_{i}=0$ dan parameter lain, misalnya $\lambda=2$, konstanta $\gamma=2, C=1$, Iterasi Maksimum = 1000000 , dan $\varepsilon=0.0001$. Kemudian menghitung matriks Hessian. 


$$
D_{i j}=y_{i} y_{j}\left(K\left(x_{i} x_{j}\right)+\lambda^{2}\right) u n t u k_{-} i, j=1, \ldots, l
$$

Keterangan :

$\begin{array}{ll}x_{i} & =\text { data ke-i } \\ x_{j} & =\text { data ke-j } \\ y_{i} & =\text { kelas data ke-i } \\ y_{j} & =\text { kelas data ke-j } \\ 1 & =\text { jumlah data } \\ K\left(x_{i} x_{j}\right) & =\text { fungsi kernel yang digunakan. }\end{array}$

b. Kemudian memulai proses iterasi mulai dari data ke-i sampai ke-j, untuk setiap pola $i=1$ sampai ke $l$,

$E_{i}=\sum_{j=1}^{l} \alpha_{i} D_{i j}$

$\delta \alpha_{i}=\min \left\{\max \left[\gamma\left(1-E_{i}\right),-\alpha_{i}\right], C-\alpha_{i}\right\}$

$\alpha_{i}=\alpha_{i}+\delta \alpha_{i}$

Keterangan :

$\gamma=$ learning rate $=$ konstanta $\gamma / \max _{\{i} D_{i j}$.

$\max _{i i} D_{i j}=$ Nilai maksimum dari diagonal matriks hessian.

c. Ulangi langkah ke-b hingga kondisi iterasi maksimum telah tercapai atau $\max \left(\left|\delta \alpha_{i}\right|\right)<\varepsilon$.

Kemudian didapatkan nilai support vector $(s v)$, $\mathrm{SV}=\left(\alpha_{i}>\right.$ treshold $)$. Nilai threshold sv didapatkan dari beberapa percobaan, biasanya digunakan threshold $\geq 0$.

3. One Against All

Strategi One-Against-All membangun sejumlah $k$ SVM biner klasifikasi, dimana setiap satu kelas terpisah dari kelas lainnya. Data training dari kelas ke- $i$ di training dengan diberi tanda positif dan semua training yang bukan dari kelas-i diberi tanda negatif [Cholissodin, Imam, Kurniati, Maya, Indriati, dan Arwani, Issa, 2014.].Penggunaan pengklasifikasian dapat dilihat pada Tabel 1.

Tabel 1. Contoh SVM dengan strategi One Against All.

\begin{tabular}{ccc}
\hline $\mathbf{y}_{\mathbf{i}}=\mathbf{1}$ & $\mathbf{Y}_{\mathbf{j}}=\mathbf{- 1}$ & $\begin{array}{c}\text { Fig. 1. } \\
\text { ipotesis }\end{array}$ \\
\hline Kelas 1 & Bukan kelas 1 & $f^{1}(x)=\left(w^{1}\right) x+b^{1}$ \\
Kelas 2 & Bukan kelas 2 & $f^{2}(x)=\left(w^{2}\right) x+b^{2}$ \\
Kelas 3 & Kelas 4 & $f^{3}(x)=\left(w^{3}\right) x+b^{3}$ \\
\hline
\end{tabular}

\section{Fuzzy-K-Nearest Neighbor}

$F K-N N$ merupakan metode gabungan dari metode logika fuzzy dengan metode K-Nearest Neighbor. Fuzzy K-Nearest Neighbor memiliki dua keunggulan utama daripada algoritma k-nearest neighbor. Pertama, algoritma ini mampu mempertimbangkan sifat ambigu dari tetangga jika ada. Algoritma ini telah dirancang sedemikian rupa agar tetangga yang ambigu tidak memainkan peranan penting dalam klasifikasi saat ini. Keunggulan kedua yaitu sebuah instance akan memiliki derajat nilai keanggotaan pada setiap kelas sehingga akan lebih memberikan kekuatan atau kepercayaan suatu instance berada pada suatu kelas [Liu, Y., Zheng, Y.F., 2005.]. Tahapan Fuzzy K-
Nearest Neighbor adalah sebagai berikut.

a. Normalisasi data, metode normalisasi data yang digunakan pada penelitian ini adalah Min Max Normalization.

b. Untuk data uji $x$ dicari $K$ tetangga terdekat menggunakan persamaan berikut

$$
\mathrm{d}\left(\mathrm{x}_{\mathrm{i}}, \mathrm{x}_{\mathrm{j}}\right)=\left(\sum_{\mathrm{l}=1}^{\mathrm{N}}\left|\mathrm{x}_{\mathrm{il}}-x_{j l}\right|^{p}\right)^{\frac{1}{p}}
$$

Keterangan:

$N=$ jumlah fitur data

$p=$ penentu jarak

- jika $p=1$ jarak yang digunakan adalah Manhattan

- jika $p=2$ jarak yang digunakan adalah Euclidean

- jika $p=\infty$ jarak yang digunakan adalah Chebyshev

c. Menghitung nilai keanggotaan dengan persamaan berikut untuk setiap $i$, dimana1 $\leq$ $i \leq C$.

$$
u\left(x, c_{i}\right)=\frac{\sum_{k=1}^{K} u\left(x_{k}, c_{i}\right) * d\left(x, x_{k}\right)^{\frac{-2}{(m-1)}}}{\sum_{k=1}^{K} d\left(x, x_{k}\right)^{\frac{-2}{(m-1)}}}
$$

Keterangan:

$u\left(x, c_{i}\right)=$ nilai keanggotaan data $x$ ke kelas $c_{i}$

$K=$ jumlah tetangga terdekat

$u\left(x_{k}, c_{i}\right)=$ nilai keanggotaan data tetangga

dalam $K$ tetangga pada kelas $c_{i}$

$d\left(x, x_{k}\right)=$ jarak dari data $x$ ke data $x_{k}$ dalam $\mathrm{K}$

tetangga terdekat

$m=$ bobot pangkat

d. Mengambil nilai terbesar dari nilai keanggotaan untuk semua $1 \leq i \leq C$.

e. Memberi label kelas $c$ ke data uji $x$.

5. Binary Decision Tree (BDT)

Metode ini menggunakan SVM yang dibuat kedalam struktur pohon biner. Sebuah SVM di setiap node dari pohon ini dilatih menggunakan dua kelas. Kemudian memproses kemungkinan output untuk mengukur kesamaan antara sampel yang tersisa dan dua kelas yang digunakan untuk pelatihan. Semua sampel di node ditugaskan untuk dua subnodes yang berasal dari kelas yang dipilih sebelumnya. Langkah ini berulang pada setiap simpul sampai setiap node hanya dapat sampel dari satu kelas [Imaduddin, Zaki, Abidzar T., Hilmy, 2015]. Langkah-langkah perhitungan algoritma dengan metode BDT-SVM yaitu sebagai berikut (Heena Farooq B. \& Mohd Arif W., 2014).

a. Identifikasi label dari data uji dan data latih.

b. Tentukan center point dari semua kelas atau label.

c. Hitung jarak dengan menggunakan Euclidean Distance diantara dua kelas $(i, j)$. 
d. Jika jarak euclidean dari pasangan kelas adalah maksimum, maka kedua kelompok kelas didapatkan dengan $i$ sebagai kelompok atau kelas pertama (subtree kiri) dan $\mathrm{j}$ sebagai kelompok atau kelas kedua (subtree kanan).

e. Menetapkan sisa kelas untuk kelompok terdekat mereka.

f. Mendapatkan classifier SVM untuk setiap pasangan kelas.

Ulangi prosedur ini sampai simpul daun mencapai yang mewakili kelas itu.

\section{HASIL DAN PEMBAHASAN}

Bagian ini berisikan mengenai hasil-hasil yang didapatkan dengan menggunakan metode yang telah diterangkan dalam bagian sebelumnya. Bagian ini dapat berisikan tabel, gambar, dan persamaan.

Jumlah data yang digunakan adalah sebanyak 140 data. Dimana terdapat 35 data setiap kelas. Dari data tersebut dibagi kedalam 2 data yaitu data training dan data testing. Selain itu juga terdapat beberapa fitur yang digunakan yaitu gabungan dari MLII dan VI (7202 fitur), MLII atau VI (3601 fitur), MLII atau VI (2161 fitur).

a. Pengujian Variasi Fitur atau Parameter

Berdasarkan hasil grafik pada Gambar 11 diketahui bahwa rata-rata tingkat akurasi terbesar yaitu $70.00 \%$ yang terdapat pada fitur 2161 atau pengambilan hasil EKG pada 6 detik. Sehingga didapatkan variasi jumlah fitur pada pengujian selanjutnya yaitu pada fitur 2161 (6 detik).

Jumlah fitur terbaik yaitu sekitar 10 detik pada kanal MLII. Untuk fitur 3601 yang merupakan pemeriksaan dari kanal VI menghasilkan akurasi sebesar $52.20 \%$ pada metode SVM. Hasil tersebut masih kecil dikarenakan pola yang terdapat pada hasil EKG untuk pemeriksaan kanal VI menghasilkan pola yang kecil karena lokasi pengambilan untuk VI terdapat di bagian dada manusia sehingga pola yang digambarkan tidak terlalu besar dengan kata lain alat EKG tidak mendeteksi denyut jantung dengan jelas. Begitu pula untuk fitur 2161 pada kanal VI dengan akurasi $30.00 \%$ pada metode BDT-SVM. Untuk fitur 7202 juga mendapatkan akurasi kecil sebesar $52.20 \%$ pada SVM karena merupakan gabungan dari kanal MLII dan VI yang menghasilkan pola yang berbeda. Akurasi terbaik pada 3601 untuk kanal MLII sebesar $81.25 \%$ pada metode SVM karena pada kanal MLII memberikan pola yang terlihat dengan jelas. Kemudian pada fitur 3601 pada kanal MLII menghasilkan akurasi $63.75 \%$ pada metode BDTSVM yang menandakan untuk pengenalan pola lebih baik pada kanal MLII. Karena MLII ini diambil di lengan dan kaki dan denyut jantung sehingga denyut jantung bisa terekam dengan jelas pada kanal MLII.
Tabel 2. Variasi Fitur

\begin{tabular}{l|c|c|c}
\hline \multirow{2}{*}{ Variasi Fitur } & \multicolumn{3}{|c}{$\begin{array}{c}\text { Metode (\%) } \\
\text { (\%) }\end{array}$} \\
\cline { 2 - 4 } & SVM & F-KNN & BDT-SVM \\
\hline $\begin{array}{l}\text { 7202 (MLII dan } \\
\text { VI) 20 detik } \\
\text { 3601 (MLII) 10 } \\
\text { detik } \\
\text { 3601 (VI) 10 } \\
\text { detik }\end{array}$ & 52.20 & 45.00 & 42.50 \\
$\begin{array}{l}\text { 2161 (MLII) 6 } \\
\text { detik }\end{array}$ & - & 80.00 & 63.75 \\
2161 (VI) 6 detik & - & - & 41.25 \\
\hline
\end{tabular}

b. Pengujian Terhadap Perbandingan Data Latih dan Data Uji

Pada pengujian perbandingan ini, rasio yang digunakan yaitu 90\%:10\%, 80\%:20\%, 70\%:30\%, 60\%:40\%, 50\%:50\%, 40\%:60\%, 30\%:70\%, 20\%:80\%, dan 10\%:90\%.

Tabel 3. Rasio Data Latih dan Uji.

\begin{tabular}{c|c|c|c}
\hline \multirow{2}{*}{$\begin{array}{c}\text { Rasio } \\
\text { Data (\%) }\end{array}$} & \multicolumn{3}{|c}{$\begin{array}{c}\text { Metode (Rata-rata akurasi } \\
(\%))\end{array}$} \\
\cline { 2 - 4 } & SVM & F-KNN & BDT-SVM \\
\hline $90: 10$ & 81.25 & 81.25 & 70.00 \\
$80: 20$ & 56.43 & 45.12 & 42.86 \\
$70: 30$ & 45.45 & 42.17 & 37.93 \\
$60: 40$ & 41.85 & 38.00 & 31.43 \\
$50: 50$ & 34.24 & 28.67 & 30.29 \\
$40: 60$ & 26.67 & 25.00 & 31.66 \\
$30: 70$ & 25.42 & 28.45 & 28.54 \\
$20: 80$ & 25.36 & 15.83 & 28.57 \\
$10: 90$ & 30.32 & 17.25 & 29.84 \\
\hline
\end{tabular}

Dengan didapatkannya nilai akurasi pada perbandingan data training yang lebih dominan maka dapat diketahui bahwa semakin tinggi nilai perbandingan data training maka akan semakin tinggi nilai akurasinya. Sehingga proses learning atau pembelajaran pada sistem bisa lebih banyak sehingga bisa mengenali pola dengan lebih baik. Pada permasalahan ini, akurasi yang didapatkan sebesar $81.25 \%$ pada metode SVM dan Fuzzy-KNN, $70.00 \%$ pada metode BDT-SVM, karena jumlah perbandingan data latih yang hanya 140 data dengan 2161 parameter masih belum bisa mengenali dengan baik pola yang ada. Pada setiap kelas pun bisa terdapat beberapa pola yang berbeda, sedangkan data setiap kelas hanya 35.

c. Pengujian Terhadap Kernel

Pengujian terhadap kernel dilakukan untuk mengetahui kernel terbaik dan pengaruh terhadap nilai akurasi. Proses pengujian dengan memasukkan 6 fungsi kernel berbeda ke dalam sistem yaitu, kernel linear, kernel polynomial degree $d$, kernel invers multi quadratic, kernel laplacian, kernel RBF, dan kernel cauchy. 


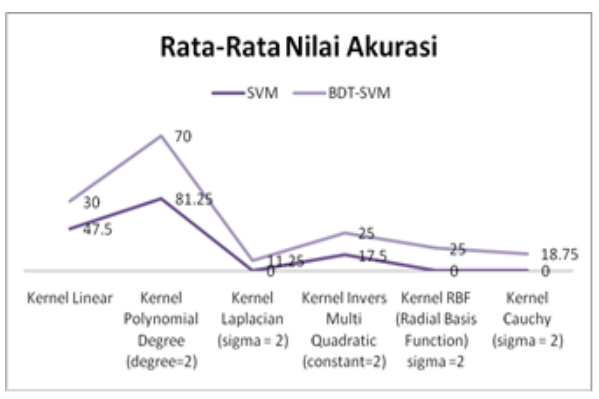

Gambar 3. Halaman Hasil Pengujian Kernel.

Dari hasil pengujian diatas didapatkan bahwa akurasi terbaik terdapat pada jenis kernel polynomial degree dengan nilai rata-rata akurasi sebesar $81.25 \%$ pada metode SVM dan $70.00 \%$ pada metode BDTSVM. Kernel polynomial adalah kernel yang baik dan cocok untuk permasalahan dimana semua data dinormalisasi. Selain itu kernel ini juga merupakan kernel non-stationary yang berarti kernel ini baik jika memiliki sebaran data dengan pola yang tidak tetap atau pola yang naik turun untuk datanya [Jowik, A. 2013].

\section{d. Pengujian Terhadap Lambda}

Inisialisasi parameter yang digunakan yaitu $\varepsilon=$ 0.00001 , iterasiMax $=100, C=1$, rasio perbandingan 90\%:10\%, gamma $=0.01$ dan nilai $d$ $=2$. Adapun hasil dari pengujian konstanta $\gamma$ (gamma) dapat dilihat pada gambar 4.

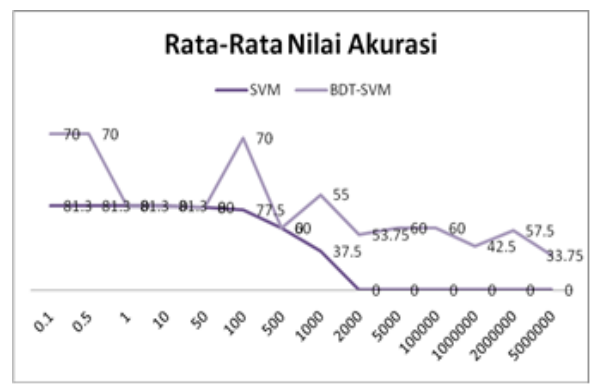

Gambar 4. Halaman Hasil Pengujian Lambda.

Gambar 4 merupakan hasil dari pengujian nilai $\lambda$ (lambda), yang mana skenario pengujian lambda memiliki nilai rata-rata tertinggi sebesar $81.30 \%$ pada metode SVM dan $70.00 \%$ pada metode BDTSVM. Semakin besar nilai nilai $\lambda$ (lambda) maka akurasi cenderung semakin kecil, dikarenakan jika nilai $\lambda$ (lambda) semakin besar akan membuat proses perhitungan komputer atau komputasi pada tahap perhitungan matriks hessian cenderung lebih lama. Saat nilai lambda kecil, maka akan membuat lebar margin menjadi mengecil dan titik bergerak dari dalam margin menuju ke luar margin sehingga mendapatkan perpotongan atau hyperplane yang baik [Souza, Caesar R. 2010].

\section{e. Pengujian Terhadap Complexity}

Inisialisasi parameter yang digunakan yaitu $\varepsilon=$
0.00001 , iterasiMax $=100$, lambda $=0.1$, rasio perbandingan 90\%:10\%, gamma $=0.01$ dan nilai $d$ $=2$. Adapun hasil dari pengujian konstanta $\gamma$ (gamma) dapat dilihat pada gambar 4.

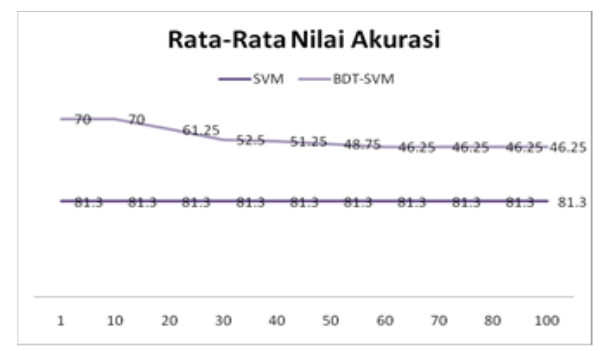

Gambar 5. Halaman Hasil Pengujian Complexity.

Berdasarkan grafik pada Gambar 5 diketahui bahwa rata-rata tingkat akurasi tertinggi sebesar $81.30 \%$ pada metode SVM dan $70.00 \%$ pada metode BDT-SVM. Tujuan adanya parameter $C$ (complexity) adalah untuk meminimalkan nilai error. Jika nilai $C$ (complexity) mendekati nilai 0 maka lebar margin pada bidang pemisah (hyperplane) menjadi maksimum, hal tersebut disebabkan karena nilai $C$ (complexity) digunakan untuk memperkecil nilai error pada proses training pada perhitungan nilai $w$ (weight) dan nilai bias, semakin kecil nilai $C$ (complexity) maka error yang terjadi pada $\alpha_{i}$ akan semakin kecil begitu pula dengan sebaliknya. Selain itu nilai $C$ (complexity) > 0 relatif penting untuk memaksimumkan margin dan meminimumkan jumlah slack [Karatzoglou, Alexandros, Meyer David, dkk, 2006.]. Parameter $C$ yang nilainya terlalu besar juga akan membuat waktu komputasi lebih lama untuk proses training data sehingga menyebabkan kurangnya konvergen (algoritma dibatalkan sebelum konvergen) [C.Cortes dan V. Vapnik, 1995].

f. Pengujian Terhadap Jarak

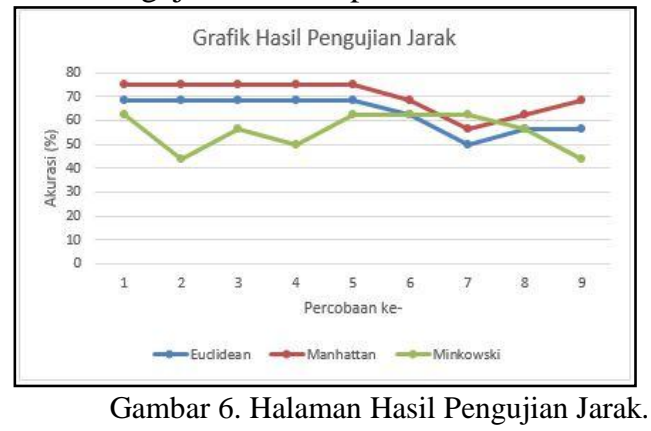

Pada pengujian ini digunakan 124 data latih, 16 data uji, nilai $\mathrm{k}=120$ dan nilai $\mathrm{m}=2$. Pengujian ini menggunakan metode Fuzzy-KNN. Berdasarkan hasil grafik di atas persentase akurasi penggunaan jarak Manhattan lebih tinggi dibandingkan jarak Euclidean maupun Minkowski, hal ini disebabkan dikarenakan dataset yang digunakan memiliki dimensi yang besar yaitu 3601. Jarak Euclidean menghitung jarak antara data uji dengan data latih dengan cara menarik garis diagonal antara titik pada 
data uji dan data latih, sedangkan jarak Manhattan menarik garis antara data uji dan data latih dari sumbu pusatnya $(0,0)$. Dimana, jika jarak ditarik dengan menggunakan garis diagonal secara langsung akan terjadi kemiripan hasil jarak data satu dengan data lainnya. Jarak Manhattan lebih tepat dan optimal saat digunakan pada data berdimensi besar menghasilkan rata-rata tertinggi yaitu sebesar $70.138 \%$ dibandingkan jarak Euclidean sebesar 63.194\% dan jarak Minkowski sebesar 55.556\%.

\section{g. Pengujian Terhadap $K$}

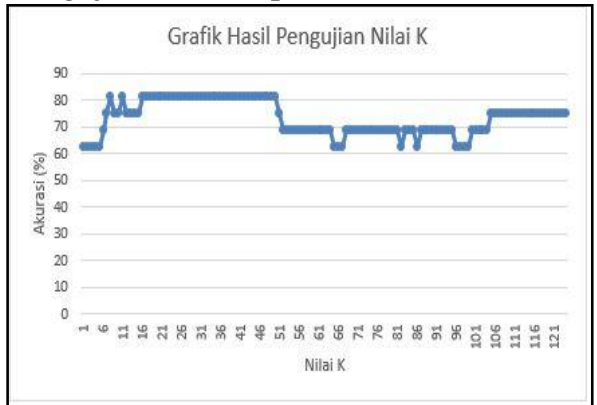

Gambar 7. Halaman Hasil Pengujian $K$.

Pengujian ini menggunakan metode Fuzzy$K N N$. Berdasarkan hasil grafik di atas disimpulkan bahwa semakin bertambahnya nilai $k$ maka akan menghasilkan nilai akurasi yang semakin tinggi tetapi akurasi akan mengalami naik turun pada nilai $k$ tertentu, namun naik turun nilai akurasi tidak stabil. Akurasi nilai $k$ tidak stabil dipengaruhi oleh sebaran data pada suatu kelas yang tidak beraturan (sebaran data tetangga pada suatu kelas yang sama dapat tersebar secara jauh maupun dekat), sehingga pemilihan nilai $k$ yang diambil akan mempengaruhi jumlah tetangga beserta sebaran dekat atau jauhnya suatu data uji terhadap data latih.Berdasarkan grafik di atas, akurasi tertinggi didapatkan dengan menggunakan 124 data latih dan 16 data uji, serta penggunaan jarak manhattan, nilai $m=2$, nilai $k$ optimal berada pada nilai $k=8, k=11, k=16$ sampai 50 yaitu sebesar $81.25 \%$.

\section{SIMPULAN}

Berdasarkan hasil penelitian dan pengujian yang dilakukan, maka dapat diambil kesimpulan yaitu Metode SVm adalah metode yang paling terbaik dari 3 metode yang digunakan dengan memberikan hasil akurasi sebesar rata-rata $81.30 \%$. Proses klasifikasi kondisi detak jantung menggunakan ini menggunakan banyaknya data latih yang masih terbatas yaitu sebesar 140 untuk semua kelas sehingga terdapat 35 data untuk setiap kelas, sedangkan parameter dari penelitian ini sebanyak 7202 (selama 20 detik), 2161 (selama 6 detik), dan 3601 (selama 10 detik). Untuk pengujian untuk parameter $\lambda$ (lambda) $=0.5$, konstanta $\mathrm{\gamma}$ $($ gamma $)=0.01, \quad \varepsilon \quad($ epsilon $)=0.00001 \quad, \quad C$ (complexity) $=1$, variasi fitur 2161, dan iterasi maksimal $=100$. Sehingga diperoleh nilai akurasi terbaik sebesar $81.30 \%$ pada metode SVM.

\section{DAFTAR PUSTAKA}

American Heart Association, 2015 Electrocardiogram (ECG) or (EKG). [online] Tersedia di <http://www.heart.org/HEARTORG/Condit ions/HeartAttack/

SymptomsDiagnosisofHeartAttack/Electrocardiogra m-ECG

EKG_UCM_309050_Article.jsp\#.VrMx_b KLTDc> [Diakses 4 Februari 2016].

Nico, 2015. Pentingnya Menjaga Kesehatan Jantung. [online] Ahli Kolesterol. Tersedia di $<$ http://ahlikolesterol.com/jantung/pentingn ya-menjaga-kesehatan-jantung > [Diakses 27 Januari 2016].

Kesehatan, Kementrian RI, 2013. Info Datin - Pusat Data dan Informasi Kementrian Kesehatan RI. Badan Litbangkes : Kementrian Kesehatan RI.

Adnamazida, Rizqi, 2013. Kardiak aritmia, Kelainan Jantung yang Mengancam Jiwa. [online] merdeka.com. Tersedia di: <http://www.merdeka.com/sehat/kardiakaritmia-kelainan-jantung-yang-mengancamnyawa.html> [Diakses 9 Februari 2016].

Amazine.co, 2016. Tips Sehat : Definisi \& 8 Gejala Aritmia (Arrhythmia) Jantung. [online] Amazine.co. Tersedia di: < http://www.amazine.co/4859/tips-sehatdefinisi-8-gejala-aritmia-arrhythmiajantung/> [Diakses 4 Februari 2016].

JJ, 2013. Apa itu EKG - Elektroardiografi. [online] SeputarJantung. Tersedia di <http://seputarjantung.com/apa-itu-ekg/> [Diakses 27 Januari 2016].

Merdeka, Suara, 2015. Perawat Dituntut Bisa Membaca Hasil Rekam EKG. [oonline] Suara Merdeka.com. Tersedia di: < http://berita.suaramerdeka.com/smcetak/per awat-dituntut-bisa-membaca-hasil-rekamekg/> [Diakses 4 Februari 2016].

FK Universitas Hasanudin, 2009. Buku Acuan Pemeriksaan EKG. [online] Skills Lab. Sistem Kardiovaskuler. Tersedia di < http://dokumen.tips/download/link/5020731 2-cara-membaca-ekgpdf> [Diakses pada 20 Maret 2016].

Imaduddin, Zaki, Abidzar T., Hilmy, 2015. Thesis Project: Aplikasi Mobile untuk Deteksi dan Klasifikasi Daun Secara Real Time. Depok : Sekolah Tinggi Teknologi Terpadu Nurul Fikri.

Madzarov, Gjorgji, Gjorgjevikj, Dejan, \& Chorbev, Ivan, 2008. Thesis projects: A Multi-class SVM Classifier Utilizing Binary Decision 
Tree. Macedonia : Department of Computer Science and Engineering.

Shu, K., Jing, L., Mei, L., Xin, Z., 2011. Prediction Based on Support Vector Machine for Travel Choice of High-Speed Railway Passenger in China, [e-journal] 10.1109/ICMSE.2011.6069938. Tersedia melalui : IEEE Xplore Digital Library < http://ieeexplore.ieee.org/stamp/stamp.jsp?t $\mathrm{p}=\&$ arnumber $=6069938>\quad$ [Diakses 9 Februari 2016].

Santoshi, G., Pushpa, G. Gowri, 2015. Thesis Project : Detect Pedestrian Orientation by Integrating Multiclass SVM Utilizing Binary Decision Tree. India : ANITS Engineering College.

Shofia, Rahmi Amiratus, dkk. 2013. Penerapan Metode Fuzzy K-Nearest Neighbor (FKNN) untuk Menentukan Kualitas Hasil Rendemen Tanaman Tebu. S1. Universitas Brawijaya Malang.

Sindo, 2010. Kenali Irama Jantung Anda. [online] Okezone.com. Tersedia di: <http://lifestyle.okezone.com/read/2010/09/ 02/27/369207/kenali-irama-jantung-anda> [Diakses 9 Februari 2016].

Pendidikan, Dosen, 2014. Pengertian Jantung dan Fungsinya pada Manusia. [online] Dosen Pendidikan.com. Tersedia di: $<$ http://www.dosenpendidikan.com/pengerti an-jantung-dan-fungsinya-pada-manusia/> [Diakses 28 Januari 2016].

The Harley Street Clinic, 2012. Gangguan Ritme Jantung. [online] The Harley Street Clinic. Tersedia di: <http://heartandcancercentre.com/id/heartdisease/types-of-heart-disease/heart-rhythmdisorders/> [Diakses 4 Februari 2016].

Cardiac Health, 2016. Bigemini. [online] Tersedia di $:<$ http://www.cardiachealth.org/bigemini> [Diakses 4 Februari 2016].

Dr. Tryzelaar, 2016. Bigemini. [online] cardiachealth.org. Tersedia di: < http://www.cardiachealth.org/bigemini> [Diakses 27 Juni 2016].

Moody, G.B., 2010. MIT-BIH Arrhythmia Database Directory. [online] Tersedia di : $<$ https://physionet.org/physiobank/database/ html/mitdbdir/intro.htm> [Diakses 8 Agustus 2016].

Point, Tutorials (I), pvt.LTD, 2014. Data Mining Data Pattern Evaluation. [e-book] pvt. LTD : Tutorials Point. Tersedia di Tutorials Point <http://www.tutorialspoint.com/data_minin g/data_mining_tutorial.pdf> [Diakses 3 Februari 2016].

Satriyo Nugroho, Anto, Budi Witarti, Arief, \& Handoko, Dwi, 2003. Support Vector Machine-Teori Aplikasinya dalam Bioinformatika. IlmuKomputer.com.

Cholissodin, Imam, Kurniati, Maya, Indriati, dan Arwani, Issa, 2014. Classification of Campus E-Complaint Documents using Directed Acyclic Graph Multi-Class SVM Based on Analytic Hierarchy Process. Malang : Universitas Brawijaya.

Liu, Y., Zheng, Y.F., 2005. One-Against-All MultiClass SVM Classification Using Reliability Measures, [e-journal] Volume 2. Tersedia melalui : IEEE Xplore Digital < http://ieeexplore.ieee.org/xpls/abs_all.jsp?ar number $=1555963>$ [Diakses 10 Februari 2016]

Jowik, A. 2013. A Learning scheme for A Fuzzy KNN Rule. Pattern Recognition Letters, vol 1, pp. 287-289

Souza, Caesar R. 2010. Kernel Function for Machine Learning Application. [online] crsouza.com. Tersedia <http://crsouza.com/2010/03/kernelfunctions-for-machine-learningapplications/\#inverse_multiquadric> [Diakses 27 Juni 2016].

Karatzoglou, Alexandros, Meyer David, dkk, 2006. Support Vector Machines in R. Jerman : Technische Universit"at Wien, Wirtschaftsuniversit" at Wien.

C.Cortes dan V. Vapnik, 1995, Machine Learning, Support Vector Networks, Vol. 20, Hal 273297.

Bucher, Gaspard, 2011. SVM Varying C and Sigma. [online] feature-space.com. Tersedia di : <http://feature-space.com/2011/11/26/svmvarying-c-and-sigma/> [Diakses 10 Agustus 2016]. 